\title{
Development and comparison of a real-time PCR assay for detection of Dichelobacter nodosus with culturing and conventional PCR: harmonisation between three laboratories
}

\author{
Sara Frosth ${ }^{1 *}$, Jannice S Slettemeås ${ }^{2}$, Hannah J Jørgensen², Øystein Angen ${ }^{3}$ and Anna Aspán ${ }^{1}$
}

\begin{abstract}
Background: Ovine footrot is a contagious disease with worldwide occurrence in sheep. The main causative agent is the fastidious bacterium Dichelobacter nodosus. In Scandinavia, footrot was first diagnosed in Sweden in 2004 and later also in Norway and Denmark. Clinical examination of sheep feet is fundamental to diagnosis of footrot, but $D$. nodosus should also be detected to confirm the diagnosis. PCR-based detection using conventional PCR has been used at our institutes, but the method was laborious and there was a need for a faster, easier-to-interpret method. The aim of this study was to develop a TaqMan-based real-time PCR assay for detection of D. nodosus and to compare its performance with culturing and conventional PCR.

Methods: A D. nodosus-specific TaqMan based real-time PCR assay targeting the 165 rRNA gene was designed. The inclusivity and exclusivity (specificity) of the assay was tested using 55 bacterial and two fungal strains. To evaluate the sensitivity and harmonisation of results between different laboratories, aliquots of a single DNA preparation were analysed at three Scandinavian laboratories. The developed real-time PCR assay was compared to culturing by analysing 126 samples, and to a conventional PCR method by analysing 224 samples. A selection of PCR-products was cloned and sequenced in order to verify that they had been identified correctly.

Results: The developed assay had a detection limit of $3.9 \mathrm{fg}$ of $D$. nodosus genomic DNA. This result was obtained at all three laboratories and corresponds to approximately three copies of the $D$. nodosus genome per reaction.

The assay showed $100 \%$ inclusivity and 100\% exclusivity for the strains tested. The real-time PCR assay found 54.8\% more positive samples than by culturing and $8 \%$ more than conventional PCR.

Conclusions: The developed real-time PCR assay has good specificity and sensitivity for detection of D. nodosus, and the results are easy to interpret. The method is less time-consuming than either culturing or conventional PCR.
\end{abstract}

\section{Background}

Footrot is a contagious bacterial disease that affects the feet of sheep, and it has been reported in many countries [1]. The fastidious and anaerobic bacterium, Dichelobacter nodosus, is the main causative agent of ovine footrot [2].

In its mildest form, footrot manifests itself as a slight inflammation of the interdigital skin of sheep, but the

\footnotetext{
* Correspondence: sara.frosth@sva.se

'Department of Bacteriology, National Veterinary Institute, SE-751 89 Uppsala, Sweden

Full list of author information is available at the end of the article
}

disease may also progress to severe necrotic separation of the claw capsule from underlying tissues. Severity of the disease depends on the breed of sheep, climatic conditions, management factors and virulence of the infecting $D$. nodosus strain.

Ovine footrot was first diagnosed in Sweden in 2004 [3], and in 2008 it was detected for the first time in 60 years in Norway [4]. In 2009, the disease was diagnosed in Denmark by culture and PCR [5], however a report on clinical disease among Danish sheep was published in 1988 [6]. The emergence of ovine footrot is a
Ciomed Central

(C) 2012 Frosth et al; licensee BioMed Central Ltd. This is an Open Access article distributed under the terms of the Creative Commons Attribution License (http://creativecommons.org/licenses/by/2.0), which permits unrestricted use, distribution, and reproduction in any medium, provided the original work is properly cited. 
challenge for the diagnostic laboratories and for the sheep industries in all three Scandinavian countries.

Clinical examination of sheep feet is fundamental to diagnosis of footrot, but detection of $D$. nodosus should also be used to confirm the diagnosis. The presence of the typical Gram-negative rods in lesion material can be confirmed by microscopy, culturing, or PCR. Cultivation of the bacterium is time consuming and laborious, and it is an advantage to also use PCR-based detection of $D$. nodosus.

A PCR method for specific detection of $D$. nodosus was developed in 1993 by La Fontaine et al. [7], and in 2005 the method was improved by Moore et al. [8] for detection of $D$. nodosus from clinical swabs. Previously, the PCR protocol published by Moore et al. [8] was used at our institutes, but there were problems with non-specific amplicons and faint bands of the correct product size which made interpretation difficult. Moreover, conventional PCR requires agarose gel electrophoresis for identification of the PCR products, making it inconvenient for the analysis of a large number of samples. A faster and more easily interpreted method, such as real-time PCR, was desirable.

The aim of this study was to develop a TaqMan-based real-time PCR assay for detection of $D$. nodosus and to compare its performance with culturing and with conventional PCR. Another goal was to compare the sensitivity of the developed real-time PCR assay between the three laboratories participating in this study since it is advantageous to be able to use the same detection method. The real-time PCR assay was developed in collaboration between the National Veterinary Institute (SVA), the Norwegian Veterinary Institute (NVI) and the National Veterinary Institute in Denmark (DTUVET). Its specificity (inclusivity/exclusivity) was tested at SVA and its sensitivity was tested and compared at all three laboratories. The SVA compared the real-time PCR assay with culturing for 126 Swedish sheep and the NVI compared it with conventional PCR for 224 Norwegian sheep.

\section{Methods}

Development of a $D$. nodosus-specific real-time PCR assay D. nodosus-specific PCR primers and a TaqMan-probe targeting the $16 \mathrm{~S}$ rRNA gene were designed using primer3 [9], producing an 84-bp fragment. The specificity of the assay was checked against GenBank sequences with the BLAST program package http://blast.ncbi.nlm. nih.gov/Blast.cgi[10]. The designed primers and TaqMan-probe were ordered from Thermo Fisher Scientific with the following sequences 5'-CGGGGTTATGTAGCTTGCTATG-3' (16Sf), 5'-TACGTTGTCCCCCACCATAA-3' (16Sr) and 5'-TGGCGGACGGGTG AGTAATATATAGGAATC-3' (16Sprobe TET-labeled).
Each $20-\mu \mathrm{l}$ PCR reaction mixture contained $1 \times$ PerfeCTa qPCR FastMix, UNG, Low Rox (Quanta BioSciences Inc., Gaithersburg, MD, USA), $0.1 \mathrm{mg} / \mathrm{ml}$ BSA (Sigma-Aldrich, St Louis, MO, USA), $0.4 \mu \mathrm{M}$ of each primer, $0.15 \mu \mathrm{M}$ of the TaqMan-probe and $2.5 \mu \mathrm{l}$ of template DNA. The PCR amplification was performed in an Applied Biosystems 7500 Fast Real-Time PCR System (Applied Biosystems, Carlsbad, CA, USA), a Stratagene Mx3005P real-time PCR thermocycler (Agilent Technologies Inc., Santa Clara, CA, USA) or in a Corbett Rotor-Gene 6000 (Qiagen, Hilden, Germany) with an initial denaturation step at $95^{\circ} \mathrm{C}$ for $10 \mathrm{~min}$, followed by 45 cycles of $95^{\circ} \mathrm{C}$ for $3 \mathrm{~s}$ and $60^{\circ} \mathrm{C}$ for $30 \mathrm{~s}$. DNA extracted from the type strain of $D$. nodosus, CCUG 27824T (Culture Collection, University of Göteborg [CCUG], Sweden) was used as a positive control in the D. nodosus-specific real-time PCR and was included in each run. Every PCR run also included a non-template control in the form of DNase- and RNase-free sterile water (Sigma-Aldrich). Fluorescence signals were analysed using an automatic setting of the threshold line in the 7500 software (v.2.0.4) and a manually set threshold of 0.01 in the softwares of the Stratagene and RotorGene real-time PCR instruments.

\section{Sensitivity of the developed real-time PCR assay and comparison of its sensitivity by three different laboratories}

The detection limit and the amplification efficiency of the D. nodosus-specific real-time PCR assay were determined using 10-fold serial dilutions of chromosomal DNA (393 ng to 3.9 ag corresponding to approximately $3 \times 10^{8}$ to $3 \times 10^{-3}$ copies of the $D$. nodosus genome per reaction) obtained from $D$. nodosus CCUG $27824 \mathrm{~T}$ (CCUG), and performing real-time PCR as described above. Each DNA dilution was run in triplicate in the real-time PCR analysis. The DNA from the D. nodosus type strain was prepared at the SVA and aliquots of the DNA preparation were sent by regular mail to the NVI and to the DTU-VET for the comparison of assay sensitivity.

\section{Inclusivity and exclusivity testing}

Fifty-five bacterial and two fungal strains were used to test the inclusivity and the exclusivity of the developed D. nodosus-specific $16 \mathrm{~S}$ real-time PCR assay (Table 1). The D. nodosus strains (except for strain CCUG $27824 \mathrm{~T}$ ) were obtained from the SVA strain collection whereas the strains of Actinobacillus pleuropneumoniae, Histophilus somni and the two Fusobacterium-strains were obtained from CCUG. The Haemophilus influenzae strain ATCC 49247 was obtained from ATCC (American Type Culture Collection). The remaining strains $(n=42)$, some of which originated from CCUG 
Table 1 Bacterial and fungal strains used for inclusivity and exclusivity testing of the developed real-time PCR assay

\begin{tabular}{|c|c|}
\hline Organism & Strain \\
\hline Dichelobacter nodosus & CCUG 27824T \\
\hline Dichelobacter nodosus & AN363/05 \\
\hline Dichelobacter nodosus & AN484/05 \\
\hline Dichelobacter nodosus & 07-BKT18497 \\
\hline Dichelobacter nodosus & 07-BKT21558 \\
\hline Dichelobacter nodosus & 07-BKT22285 \\
\hline Dichelobacter nodosus & 07-BKT24952 \\
\hline Dichelobacter nodosus & 08-BKT63297 \\
\hline Dichelobacter nodosus & 09-BKT91977(5) \\
\hline Dichelobacter nodosus & 09-BKT94362(4) \\
\hline Actinobacillus pleuropneumoniae & CCUG 12837 \\
\hline Bacillus anthracis & 7702 \\
\hline Bacillus anthracis & 4429 \\
\hline Bacillus cereus & B. cereus \\
\hline Campylobacter coli & SLV-271 \\
\hline Campylobacter jejuni & SLV-542 \\
\hline Enterobacter cloacae & SLV-011 \\
\hline Enterococcus durans & SLV-078 \\
\hline Escherichia coli & U226 \\
\hline Escherichia coli & B266 \\
\hline Escherichia coli & L278 \\
\hline Escherichia coli & UM245 \\
\hline Escherichia coli & S262 \\
\hline Escherichia coli & XL-1 blue \\
\hline Escherichia coli EIEC & 121 \\
\hline Escherichia coli O113:H21 & 98NK2 \\
\hline Escherichia coli 0157 & SLV-479 \\
\hline Escherichia coli 0157 & EDL933 \\
\hline Escherichia coli O157:H- & 493/89 \\
\hline Escherichia coli O26:H11 & H2954/06 \\
\hline Francisella tularensis & T8 \\
\hline Fusarium culmorum & F.C \\
\hline Fusarium graminearum & F.g \\
\hline Fusobacterium necrophorum subsp. funduliforme & CCUG 42162 \\
\hline Fusobacterium necrophorum subsp. necrophorum & CCUG 9994 \\
\hline Haemophilus influenzae & ATCC 49247 \\
\hline Histophilus somni & CCUG 28029 \\
\hline Klebsiella pneumoniae & SLV-186 \\
\hline Listeria ivanovii & SLV-348 \\
\hline Listeria monocytogenes & SLV-513 \\
\hline Proteus mirabilis & SLV-374 \\
\hline Pseudomonas aeruginosa & SLV-395 \\
\hline Pseudomonas aeruginosa & SLV-453 \\
\hline Salmonella Dublin & SLV-242 \\
\hline Salmonella Typhimurium & SLV-248 \\
\hline Shigella boydii & $33 / 08$ \\
\hline Shigella dysenterieae & $15 / 08$ \\
\hline Shigella flexneri & 100/08 \\
\hline Shigella sonnei & $99 / 08$ \\
\hline
\end{tabular}

Table 1 Bacterial and fungal strains used for inclusivity and exclusivity testing of the developed real-time PCR assay (Continued)

\begin{tabular}{ll}
\hline Staphylococcus aureus & SLV-438 \\
Staphylococcus xylosus & SLV-283 \\
Vibrio cholerae & CCUG 4070 \\
Vibrio parahaemolyticus & CCUG 4224 \\
Vibro vulnificus & CCUG 16397 \\
Yersinia enterocolitica & SLV-408 \\
Yersinia pestis & KIM \\
Yersinia pseudotuberculosis & TAVA81 \\
\hline
\end{tabular}

and some from the SVA strain collection, were received as DNA preparations from the Swedish Food Administration (NFA, Uppsala, Sweden) in the form of an exclusivity panel. DNA for inclusivity and exclusivity testing was extracted from colony material as described below. DNA provided by the NFA was prepared using a BioRobot EZ1 (Qiagen) and the Fusobacterium-DNA was prepared by a spin-column procedure (QIAamp DNA Mini Kit, Qiagen). A NanoDrop 1000 spectrophotometer (Thermo Fisher Scientific Inc., Wilmington, DE, USA) was used to measure the DNA concentrations before inclusivity and exclusivity testing. The DNA preparations were diluted in double distilled water to $2.0 \mathrm{ng} / \mu \mathrm{l}$ and subjected to real-time PCR analysis in duplicate, on two different occasions, as described above.

\section{Comparison with culturing}

A total of 126 Swedish sheep with clinical signs of footrot (score $\geq 2$ foot lesions) were sampled during 2009 with the scoring system (0-5) described by Stewart and Claxton [11]. The definition of a score 2 lesion, upon which the footrot diagnosis is based in Sweden, is a necrotising inflammation of the interdigital skin involving part or all of the soft horn of the axial wall of the digit [11].

Samples were taken from the interdigital skin of the feet both for culturing and for direct real-time PCR analysis. For culturing, samples were collected using a sterile wooden stick, which was placed in Amies transport medium with charcoal (Copan Innovation Ltd, Brescia, Italy). For direct real-time PCR analysis, sample material was collected using a swab (ESwab, Copan Innovation Ltd). The samples were sent in padded envelopes by regular mail to SVA where they usually arrived within 24 hours of sampling. The samples were cultivated on hoof agar plates as described by Stewart and Claxton [11] on the day of arrival at the laboratory. The plates were incubated anaerobically at $37^{\circ} \mathrm{C}$ and were read after four to six days. Typical colonies were subcultured and identified on the basis of characteristic colony 
appearance, Gram stain and also by the real-time PCR assay specific for $D$. nodosus developed in this study.

DNA was extracted from swabs or from bacterial colonies. The swabs were first shaken for $5 \mathrm{~min}$ at 700$800 \mathrm{rpm}$ before the fluid was transferred to a $2.0-\mathrm{ml}$ microcentrifuge tube and centrifuged for $5 \mathrm{~min}$ at 13 $000 \mathrm{~g}$. The supernatant was discarded and the pellet was resuspended in $200 \mu \mathrm{l}$ of G2-Lysis Buffer (Qiagen). Twenty-five microliters of proteinase K (Qiagen) was added to the pellet and lysis buffer solution before lysis of the samples in a thermomixer comfort (Eppendorf, Hamburg, Germany) at $54^{\circ} \mathrm{C}$ and $300 \mathrm{rpm}$ for $10 \mathrm{~min}$. DNA extraction was performed in a BioRobot EZ1 (Qiagen) according to the manufacturer's instructions using the EZ1 Tissue Kit and the bacterial protocol from the same manufacturer. The elution volume was $100 \mu \mathrm{l}$ and the eluate was used as template in the PCR reactions. When DNA was prepared from colony material, a loopful of bacterial colonies was picked and suspended in $450 \mu \mathrm{l}$ of double distilled water which was incubated at $96^{\circ} \mathrm{C}$ for $15 \mathrm{~min}$ and then immediately placed on ice for at least $10 \mathrm{~min}$. After centrifugation for $5 \mathrm{~min}$ at 13 $000 \mathrm{~g}$ the supernatant was used as template in the PCR reactions.

Contamination controls in the form of sterile swabs were extracted after every fifth swab processed in the DNA extraction robot. These were used as templates in the real-time PCR, in addition to a non-template control and a positive control which were included in each run.

Samples that were negative for the 16S rRNA gene of $D$. nodosus $(n=23)$ were amplified a second time with the TaqMan Exogenous Internal Positive Control Reagents (Applied Biosystems); this is an internal amplification control (IAC) for distinguishing true target negatives from PCR inhibition. The same conditions as for the $16 \mathrm{~S}$ assay were used except that the $16 \mathrm{~S}$ primers and probe were replaced by the control reagents.

Results from the comparison of the real-time PCR vs. culturing were plotted in a $2 \times 2$ table, and the agreement between results from the two methods was assessed using the kappa statistic for concordance and McNemar's test for discordance [12].

\section{Comparison with conventional PCR}

The 224 samples for comparing the developed real-time PCR with conventional PCR were collected in Norway during 2008 and 2009. The samples were submitted to the NVI as diagnostic samples and the clinical status of the animals was unknown. A sterile wooden stick was used to collect the samples from the interdigital skin of the feet. The wooden stick was placed in a tube with sterile phosphate buffered saline (PBS) containing 0.02 $M$ EDTA and sent to the NVI by regular mail. DNA was extracted from the samples by applying $200 \mu \mathrm{l}$ of
PBS/EDTA in a NucliSENS ${ }^{\circledR}$ easyMAG ${ }^{\circledR}$ extraction robot (bioMérieux, Marcy l'Etoile, France) according to the manufacturer's instructions. A prolonged lysis of ten minutes was used and the elution volume was $60 \mu \mathrm{l}$.

The samples were analysed using both the real-time PCR developed in this study and the conventional PCR published by Moore et al. [8] The conventional PCR method is based on amplification of a 783-bp product of the $16 \mathrm{~S}$ rRNA gene of $D$. nodosus. Conventional PCR amplifications were carried out in an MJ Research DNA Engine DYAD ${ }^{\circledR}$ PTC-0220 thermal cycler (Bio-Rad Laboratories AB, Hercules, CA, USA) with conditions described by Moore et al. [8]. Amplified DNA was run on a $1 \%$ agarose gel and visualized under UV light using a GelDoc Molecular Imager (Bio-Rad Laboratories AB).

Results from samples with high Ct values in the realtime PCR, and samples that were positive by the realtime PCR but were negative or had faint bands in the conventional PCR were cloned and sequenced for verification. These samples were run by block PCR using the real-time PCR primers, and the 84-bp PCR product was cloned using TOPO $^{\circledR}$ TA Cloning ${ }^{\circledR}$ Kit for Sequencing (Invitrogen, Carlsbad, CA, USA) according to the manufacturer's instructions. Sequencing was performed on a capillary electrophoresis ABI-PRISM ${ }^{\circledR} 3130 x l$ Genetic Analyzer (Applied Biosystems) using BigDye ${ }^{\circledR}$ Terminator v1.1 Cycle Sequencing Kit (Applied Biosystems) according to the manufacturer's instructions. The 10- $\mu \mathrm{l}$ reaction mixture included $4 \mu \mathrm{l}$ BigDye ${ }^{\circledR}$ Terminator v1.1 sequencing mix, $0.5 \mu \mathrm{l}$ primer (M13.F or M13.R), $2.5 \mu \mathrm{l}$ ultrapurified water and $3 \mu \mathrm{l}$ template DNA. The reaction mixture was run on a Dyad Thermal Cycler with the following conditions: denaturation at $95^{\circ} \mathrm{C}$ for 3 min, followed by 60 cycles containing denaturation $95^{\circ} \mathrm{C}$ for $45 \mathrm{~s}$, annealing $50^{\circ} \mathrm{C}$ for $20 \mathrm{~s}$ and elongation $60^{\circ} \mathrm{C}$ for 4 min. DNA sequences were analysed using CLC Main Workbench (CLC bio, Aarhus, Denmark).

Results from the comparison of the conventional PCR vs. real-time PCR were plotted in a $2 \times 2$ table, and the agreement between results from the two methods was assessed using the kappa statistic for concordance and McNemar's test for discordance [12].

\section{Results}

Sensitivity of the developed real-time PCR assay and comparison of its sensitivity by the three different laboratories

DNA dilutions of $393 \mathrm{ng}$ to $3.9 \mathrm{fg}$ per PCR reaction were positive for all three replicates and were used to construct a standard curve and to determine the minimal limit of detection. The standard curve had a slope of -3.396 ( $\mathrm{R}^{2}$ 0.998) corresponding to an amplification efficiency of $97.0 \%$ for the assay. The minimum detection limit of the developed real-time PCR assay was 3.9 
Table 2 Comparison of real-time PCR and culturing

\begin{tabular}{lccc}
\hline & $\begin{array}{c}\text { Culturing } \\
\text { positive }\end{array}$ & $\begin{array}{c}\text { Culturing } \\
\text { negative }\end{array}$ & Total \\
\hline $\begin{array}{l}\text { Real-time PCR positive } \\
\begin{array}{l}\text { Real-time PCR } \\
\text { negative }\end{array}\end{array}$ & 34 & 69 & 103 \\
\hline Total & 0 & 23 & 23 \\
\hline
\end{tabular}

fg of D. nodosus genomic DNA, corresponding to approximately three copies of the $D$. nodosus genome per PCR reaction. In the assay sensitivity comparison study, the same detection limit was obtained at all three laboratories.

\section{Inclusivity and exclusivity testing}

The developed real-time PCR assay showed 100\% inclusivity for the 10 D. nodosus strains tested and $100 \%$ exclusivity for 45 non-target bacterial strains and two non-target fungal strains (Table 1).

\section{Comparison with culturing}

Of the 126 sheep with clinical signs of footrot (score $\geq 2$ foot lesions), 103 (81.7\%) sheep were positive for $D$. nodosus by the real-time PCR assay developed and 34 sheep (27.0\%) were positive for $D$. nodosus by culturing (Table 2). The real-time PCR method found $54.8 \%$ more $D$. nodosus-positive sheep than the culturing method. The 23 samples that were negative by the $D$. nodosusspecific real-time PCR assay were all positive for the internal amplification control (IAC), which rules out negative results due to PCR inhibition.

A kappa value of 0.15 indicated slight agreement between the real-time PCR and culturing [12]. The relatively low value was due to the great sensitivity difference between the methods. The McNemar test value of 67 ( $\mathrm{p}<0.0001)$ indicates a significant difference between the two methods - the real-time PCR method detected more positive samples than did culturing.

\section{Comparison with conventional PCR}

Results from the comparison study where 224 samples were analysed by both the developed real-time PCR and conventional PCR are presented in a $2 \times 2$ table (Table $3)$. Forty-seven (21\%) of the samples had weak bands in

Table 3 Comparison of real-time PCR and conventional PCR (C-PCR)

\begin{tabular}{lccc}
\hline & C-PCR positive & C-PCR negative & Total \\
\hline Real-time PCR positive & $71^{\mathrm{a}}$ & 17 & 88 \\
Real-time PCR negative & 0 & $136^{\mathrm{b}}$ & 136 \\
\hline Total & 71 & 153 & 224 \\
\hline
\end{tabular}

${ }^{\mathrm{a}} 34$ of the samples run by C-PCR were sequenced; ${ }^{\mathrm{b}} 13$ of the samples run by C-PCR were sequenced. the conventional PCR, and were sequenced for verification. Sequences were obtained for all these samples, and BLAST searches verified 34 and 13 of the samples as positive and negative for $D$. nodosus, respectively. The 13 samples that were negative for $D$. nodosus by sequencing were simultaneously negative by real-time PCR. Without the sequencing these would have represented false positive results by the conventional PCR. The 34 samples that had weak bands by conventional PCR (and that were verified as $D$. nodosus positive by sequencing) were simultaneously positive by the real-time PCR.

Hence, taking results from sequencing into consideration, there were differences between real-time PCR and conventional PCR in 17 of the 224 samples. In all of these 17 cases, real-time PCR was positive and conventional PCR was negative, and the real-time PCR products were successfully cloned and sequenced. A BLAST search verified all the 17 samples as $D$. nodosus with a $100 \%$ score http://blast.ncbi.nlm.nih.gov/Blast.cgi.

A kappa value of 0.84 indicated good agreement between the two methods [12], but the McNemar test value was 15.1 ( $\mathrm{p}<0.0001)$ indicating a significant difference between the two methods - the real-time PCR method detected more positive samples than the conventional PCR.

\section{Discussion}

Good diagnostic tools are essential to identify the presence of $D$. nodosus and to study its epidemiology. Such knowledge is important to limit and control footrot, a disease that constitutes a major animal welfare problem. A correct diagnosis is a prerequisite to distinguish footrot from other diseases or conditions that can affect the feet of sheep such as contagious ovine digital dermatitis (CODD), white line disease, granulomas and toe and pedal joint abscesses [13].

Footrot is often introduced into a sheep flock by the purchase of an infected animal and transmission within a flock occurs mainly from sheep to sheep via the environment [14]. The environment can also be a source for introduction of footrot as reported by Whittington et al. [15] where a flock became infected after using the same yard used by an infected flock some hours earlier. The risk of introduction or re-introduction of footrot into a flock can be reduced by some principal preventive strategies as described by Abbott and Lewis [16]: animals should only be purchased from footrot-free flocks, purchased animals should be quarantined, or the flock should be sequestered from outside introduction.

In this study, a TaqMan-based real-time PCR assay targeting the 16S rRNA gene for the detection of $D$. nodosus in clinical samples was developed in collaboration between SVA, NVI and DTU-VET. The approach was chosen with the aim of improving detection of $D$. 
nodosus compared to traditional culturing and conventional PCR. The real-time PCR assay was compared to culturing for 126 Swedish sheep by the SVA and to conventional PCR for 224 Norwegian sheep by the NVI. Its specificity (inclusivity/exclusivity) was tested at SVA and its sensitivity was tested and compared at all three laboratories. It is an advantage that the same detection method with the same sensitivity can be used in the three different Scandinavian countries, so that results can be easily compared.

Another real-time PCR targeting D. nodosus has recently been published by Calvo-Bado et al. [17] but its emphasis is on quantification rather than detection. This assay is based on the rpoD gene which is a single copy gene in the $D$. nodosus genome while the developed real-time PCR in this study is based on the $16 \mathrm{~S}$ rRNA gene which exists in three copies [18]; this is an advantage when sensitive detection is required.

There was a significant difference between the realtime PCR assay and culturing with the real-time PCR method being three times more sensitive in detecting positive samples. This is not surprising because $D$. nodosus is a fastidious organism that can be difficult to culture, particularly when samples are not plated immediately. It was, however, somewhat surprising that the total number of real-time PCR positive samples was not higher $(81.7 \%)$ as all samples were from sheep with clinical signs of footrot (score $\geq 2$ foot lesions). One explanation could be that sampling, which took place in the field and by different persons, was not optimal and that sample quality deteriorated in the post. In a footrot prevalence study by König et.al. [19], in which sampling took place at the laboratory and by the same persons, $97 \%$ of the samples from sheep with score 2 footrot lesions were found positive with the same real-time PCR developed in this study and $79 \%$ by culturing.

When weak bands in the conventional PCR were sequenced there was good agreement between conventional PCR and the developed real-time PCR method. However, the real-time PCR method detected $8 \%$ more positive samples compared to the conventional PCR.

In the 13 samples found to be negative by the realtime PCR, the conventional PCR gave a faint band of approximately the correct size. Without sequencing, these samples could have been incorrectly interpreted as D. nodosus positive. At the NVI this was a severe problem when $D$. nodosus diagnostics were first implemented there. Of approximately 6000 samples analysed by the conventional PCR in a screening study in 2008 [20], $11 \%$ had to be sequenced due to diffuse bands. Of the sequenced samples, $75 \%$ of these were found not to be D. nodosus after a BLAST search (Jannice S Slettemeås, personal communication).
A main advantage with the probe-based, real-time PCR over conventional PCR is that it eliminates non-specific amplicons and faint bands of the correct product size. A great proportion $(21 \%)$ of the conventional PCR products had to be sequenced. The real-time PCR is more sensitive, less time consuming and laborious, and does not involve post-PCR processing. A greater sensitivity of realtime PCR compared to conventional PCR has also been shown in previous studies [21] and [22]. Real-time PCR is a good tool for identifying slow-growing bacteria like D. nodosus. Probe-based real-time PCR provides specificity, i.e. it limits some of the nonspecific fluorescence signals toward the end of the reaction [23].

There were no signs of inhibition in the developed real-time PCR assay in this study, but inhibitors can vary with sample material. Inhibition is also dependent on the DNA purification method used, so one should run an IAC simultaneously with the samples or in a subsequent assay.

\section{Conclusions}

The developed real-time PCR assay is a specific and easy-to-interpret method for detection of D. nodosus, and it is more sensitive and faster than either culturing or conventional PCR. There is an advantage that the same detection method is used in the three Scandinavian countries, so that results can be easily compared. A rapid and reliable detection method will aid in diagnosis and efforts to reduce the incidence of, or even to eradicate, virulent footrot in sheep populations. The developed real-time PCR is, however, not intended as a replacement for culturing as isolation of $D$. nodosus is still required for virulence testing and fingerprinting. However, it is a good complement to the laborious conventional culturing techniques.

Future studies could include determining the detection limit of $D$. nodosus in artificially contaminated swab samples. In addition, an IAC could be incorporated in the real-time PCR assay instead of running it separately as today.

\section{Acknowledgements}

We thank Gull Holmström and Ulla Zimmerman at the Department of Bacteriology (SVA) and Lene Hermansen and Bereket Tesfamichael at the Section for Bacteriology (NVI) for excellent technical assistance. We also thank Kerstin Ekström at the Department of Animal Health and Antimicrobial Strategies (SVA) for providing the Fusobacterium-DNA, Catarina Nilsson at the Swedish Food Administration (NFA) for providing the exclusivity panel and Ulrika König for comments on the manuscript. Animalia - Meat and Poultry Research Centre, SVA's research fund, the Swedish Board of Agriculture, the Swedish Animal Health Service and the Swedish Farmers' Foundation for Agricultural Research (SLF) are gratefully acknowledged for their financial contribution to the study.

\section{Author details}

${ }^{1}$ Department of Bacteriology, National Veterinary Institute, SE-751 89 Uppsala, Sweden. ${ }^{2}$ Norwegian Veterinary Institute, P. O. Box 750 Sentrum, N-0106 
Oslo, Norway. ${ }^{3}$ National Veterinary Institute, Technical University of Denmark, Bülowsvej 27, DK-1790 Copenhagen V, Denmark.

\section{Authors' contributions}

The study was designed by SF and AA. SF, JSS and ØA performed the laboratory work and the analysis of results was done by all authors. HJJ performed all statistical calculations. SF drafted the manuscript and all authors revised, read and approved the final manuscript.

\section{Competing interests}

The authors declare that they have no competing interests.

Received: 23 June 2011 Accepted: 31 January 2012

Published: 31 January 2012

\section{References}

1. Bennett GN, Hickford JG: Ovine footrot: new approaches to an old disease. Vet Microbiol 2011, 148:1-7.

2. Beveridge WIB: Foot-rot in sheep: a transmissible disease due to infection with Fusiformis nodosus (n.sp.). Studies on its Cause, Epidemiology and Control Melbourne (Bulletin No. 140): Council for Scientific and Industrial Research; 1941, 1-56.

3. Olofsson A, Bergsten C, Björk Averpil H: Smittsam klövsjukdom hos får diagnostiserad för första gången i Sverige (Infectious claw disease diagnosed for the first time in Sweden). Svensk Vet Tidn 2005, 11:11-14, (In Swedish, with English summary).

4. Meling S, Ulvund MJ: Flock health visits in 17 sheep flocks in Rogaland Proceedings of the 7th International Sheep Veterinary Congress; Stavanger, Norway 2009.

5. Angen $\varnothing$, Akkad NB, Klaas I: Detection of Dichelobacter nodosus in Danish sheep flocks by real-time PCR. 1st congress of the European Association of Veterinary Laboratory Diagnosticians (EAVLD); Lelystad, the Netherlands 2010.

6. Jørgensen RJ: Fårets ondartede klovesyge. Dansk Vet Tidsskr 1988, 71:431-434, (In Danish).

7. La Fontaine S, Egerton JR, Rood JI: Detection of Dichelobacter nodosus using species-specific oligonucleotides as PCR primers. Vet Microbiol 1993, 35:101-117.

8. Moore L, Wassink GJ, Green LE, Grogono-Thomas R: The detection and characterisation of Dichelobacter nodosus from cases of ovine footrot in England and Wales. Vet Microbiol 2005, 108:57-67.

9. Rozen S, Skaletsky H: Primer3 on the WWW for general users and for biologist programmers. Methods Mol Biol 2000, 132:365-386.

10. Altschul SF, Gish W, Miller W, Myers EW, Lipman DJ: Basic local alignment search tool. J Mol Biol 1990, 215:403-410.

11. Stewart DJ, Claxton PD: Ovine foot rot: Clinical diagnosis and bacteriology. In Australian standard diagnostic techniques for animal diseases. Edited by: Corner LA. Bagust TJ: CSIRO; 1993:1-27.

12. Altman DG: Practical statistics for medical research London: Chapman and Hall; 1991

13. Winter AC: Lameness in sheep. Small Ruminant Research 2008, 76:149-153.

14. Green LE, George TR: Assessment of current knowledge of footrot in sheep with particular reference to Dichelobacter nodosus and implications for elimination or control strategies for sheep in Great Britain. Vet J 2008, 175:173-180.

15. Whittington RJ: Observations on the indirect transmission of virulent ovine footrot in sheep yards and its spread in sheep on unimproved pasture. Aust Vet J 1995, 72:132-134.

16. Abbott KA, Lewis CJ: Current approaches to the management of ovine footrot. Vet J 2005, 169:28-41.

17. Calvo-Bado LA, Oakley BB, Dowd SE, Green LE, Medley GF, UI-Hassan A, Bateman V, Gaze W, Witcomb L, Grogono-Thomas R, et al: Ovine pedomics: the first study of the ovine foot $16 \mathrm{~S}$ rRNA-based microbiome. ISME J 2011.

18. La Fontaine S, Rood J: Organization of ribosomal RNA genes from the footrot pathogen Dichelobacter nodosus. Microbiology 1996, 142(Pt 4):889-899.

19. König U, Nyman A-KJ, de Verdier K: Prevalence of footrot in Swedish slaughter lambs. Acta Vet Scand 2011, 53:27.
20. Vatn S, Hektoen L, Høyland B, Kampen AH, Skarra TK: Surveillance, control and eradication of footrot in Norway. Proceedings of the 7th International Sheep Veterinary Congress; Stavanger, Norway 2009.

21. Deschaght P, De Baere T, Van Simaey L, Van Daele S, De Baets F, De Vos D, Pirnay JP, Vaneechoutte M: Comparison of the sensitivity of culture, PCR and quantitative real-time PCR for the detection of Pseudomonas aeruginosa in sputum of cystic fibrosis patients. BMC Microbiol 2009, 9:244.

22. Kim DM, Park G, Kim HS, Lee JY, Neupane GP, Graves S, Stenos J: Comparison of conventional, nested, and real-time quantitative PCR for diagnosis of scrub typhus. J Clin Microbiol 2011, 49:607-612.

23. Caraguel CG, Stryhn H, Gagne N, Dohoo IR, Hammell KL: Selection of a cutoff value for real-time polymerase chain reaction results to fit a diagnostic purpose: analytical and epidemiologic approaches. J Vet Diagn Invest 2011, 23:2-15.

doi:10.1186/1751-0147-54-6

Cite this article as: Frosth et al:: Development and comparison of a realtime PCR assay for detection of Dichelobacter nodosus with culturing and conventional PCR: harmonisation between three laboratories. Acto Veterinaria Scandinavica 2012 54:6.

\section{Submit your next manuscript to BioMed Central and take full advantage of:}

- Convenient online submission

- Thorough peer review

- No space constraints or color figure charges

- Immediate publication on acceptance

- Inclusion in PubMed, CAS, Scopus and Google Scholar

- Research which is freely available for redistribution

Submit your manuscript at www.biomedcentral.com/submit
C Biomed Central 